\title{
Suppression of Tumor Necrosis Factor Production by Alcohol in Lipopolysaccharide-Stimulated Culture
}

\author{
Madhavan P. N. Nair, Stanley A. Schwartz, Ziad A. Kronfol, Elizabeth M. Hill, Ann M. Sweet, and John F. Greden
}

\begin{abstract}
Many studies have shown that alcohol consumption is associated with alteration in immune responses and increased incidence of infection in the host. Tumor necrosis factor (TNF) is a potent soluble mediator of immunoregulation and inflammation, and plays a very important role in host's defenses against infection and tumor. We propose that one of the mechanisms of alcohol-mediated immunosuppression may be due to a defect in the synthesis and release of the TNF. To determine this, we studied the direct effect of alcohol on lipopolysaccharide (LPS)-induced TNF production by whole blood and total mononuclear cell from normal subjects. Aliquots of blood samples (1 ml) or ficoll-hypaque separated total mononuclear cells $\left(1 \times 10^{6} / \mathrm{ml}\right)$ were cultured with different concentrations of either ethanol or acetaldehyde in the presence or absence of LPS for $4 \mathrm{hr}$ at $37^{\circ} \mathrm{C}$. Plasma samples and culture supernatants were assayed for TNF levels in a bioassay using a TNF-sensitive WEHI 164 subclone 13 cell line. LPS at $10 \mu \mathrm{g} / \mathrm{ml}$ produced a maximal level of TNF compared with lower $(1 \mu \mathrm{g} / \mathrm{ml})$ or higher concentration $(50 \mu \mathrm{g} / \mathrm{ml})$ of L.PS. Kinetics studies showed that an incubation time of $4 \mathrm{hr}$ with LPS produced a maximum level of TNF production by blood. Alcohol, as low as $0.1 \%$ concentration, produced significant suppression of LPS-inducted TNF production by whole blood, whereas alcohol at 0.2 and $0.3 \%$ concentrations were required to produce a significant suppression of TNF production by separated mononuclear cells. Anti-TNF- $\alpha$ antibodies significantly neutralized the LPS-induced TNF that suggests that blood monocytes may be the primary source of TNF production. Further, significant correlation between TNF production and monocyte numbers was observed. Acetaldehyde one of the primary metabolites of alcohol, did not suppress the LPS-induced TNF production by whole blood. These studies suggest that alcoholinduced inhibition of TNF may be one of the mechanisms for immunosuppression in alcoholic patients.
\end{abstract}

Key Words: Tumor Necrosis Factor, Immunoregulation, Alcohol.

$\mathbf{T}$ HE BODY'S ability to mount an antigen-specific response is directly dependent on the production of multiple immunoregulatory proteins, cytokines. ${ }^{1,2}$ Tumor necrosis factor (TNF) is an important cytokine that is known to be involved in defense mechanisms against tumor and infectious and inflammatory diseases. ${ }^{1,3}$ Pre-

From the Department of Medicine, State University of New York at Buffalo (M.P.N.N., S.A.S., A.M.S.), Buffalo, New York; and the Department of Psychiatry, the University of Michigan (Z.A.K., E.M.H.) and the Alcohol Research Center (Z.A.K., E.M.H., J.F.G.), Ann Arbor, Michigan. 1993

Received for publication August 17, 1992; accepted November 16,

This work was supported, in part, by the National Institutes of Health Grants I P50 AA07378, ROI CA 35922, MH42988, and 1 ROI MH 47225.

Reprint requests: Madhavan P. N. Nair, Ph.D., Associate Professor of Medicine, State University of New York at Buffalo, 100 High Street, Buffalo. NY 14203.

Copyright $@ 1994$ by The Research Society on Alcoholism. 602 vious studies showed that TNF modulates the functions of polymorphonuclear neutrophils, ${ }^{4} \mathrm{~T}$-cells, ${ }^{5,6} \mathrm{~B}$-cells,,${ }^{7,10}$ monocyte/macrophages, ${ }^{11}$ natural killer (NK), ${ }^{12}$ and lymphokine-activated killer (LAK) cells. ${ }^{13}$ TNF also interacts with other cytokines, particularly interferon- $\gamma$, granulocyte-macrophage colony-stimulating factor, and interleukin (IL)-1, IL-2, and IL-4. ${ }^{14-17}$ Thus, TNF plays an important role in the host's defense mechanisms. Previous studies have shown that chronic alcohol consumption is associated with dysfunctions of immune system. ${ }^{18-34} \mathrm{We}$ have earlier reported that the lymphocytes from nonalcoholic healthy donors precultured in vitro with different concentrations of alcohol manifested decreased level of NK and antibody-dependent cellular cytotoxic (ADCC), and LAK cell activities. ${ }^{35}$ We have demonstrated that alcohol has a selective inhibitory effect on NK activity of lymphocytes from acquired immunodeficiency syndrome (AIDS) patients. ${ }^{36}$ Recent studies showed that acute alcohol intoxication in rats markedly suppressed both serum and lung TNF, elicited in response to lipopolysaccharide (LPS) ${ }^{37}$ and intratracheal challenge with Staphylococcus aureus or Klebsiella pneumonia. ${ }^{38}$ These studies suggest that altered TNF release may have a role in the reduced immune response to infections in alcoholics. Although a number of in vitro and in vivo studies reported that alcohol modulates immune responses, the mechanisms by which alcohol alters these functions remains unclear. The present study was undertaken to investigate the direct effect of alcohol on TNF production by whole blood cells and separated total mononuclear cells in response to LPS in vitro.

\section{MATERIALS AND METHODS}

\section{Blood Donors}

Blood donors were apprised of this study, and consents were obtained consistent with the policies of the appropriate institutions and the National Institutes of Health. Peripheral blood from a total of 36 healthy, human immunodeficiency virus (HIV) seronegative, nonalcoholic individuals was drawn into a syringe containing heparin $(20$ units $/ \mathrm{ml})$. Subjects were free of medical or psychiatric illness and were not taking medications known to affect immune functions, including nonsteroidal antiinflammatory agents and substances of abuse. The age of the subjects ranged from 20 to 40 years. For each set of experiments, different blood donors were used, and no blood samples/blood donors were used interchangeably. For each blood sample, a white blood cell count was obtained using a coulter counter (Coulter Electronics, Hialeach, FL). A blood 
smear was also made and stained with Diff-Quik (Scientific Products, McGaw Park, IL) for a differential count.

\section{Experimental Design}

Total mononuclear cells were separated by ficoll-hypaque centrifugation, and the cells were washed three times in $\mathrm{Ca}^{2+}-\mathrm{Mg}^{2+}$ free Hank's balanced salt solution. In experiments using whole blood samples, $1 \mathrm{ml}$ of blood samples was aliquoted rapidly into sterile eppendorf tubes. In experiments using separated mononuclear cells, one million cells were cultured in complete medium containing $5 \%$ fetal bovine serum (FBS) (GIBCO), $300 \mu \mathrm{g} / \mathrm{ml}$ of fresh flutamine, and $80 \mu \mathrm{g}$ gentamicin $/ \mathrm{ml}$ (complete medium). Triplicates of blood samples and mononuclear preparations received ethanol (EtOH) at $0.1,0.2$, and $0.3 \%$ final concentrations and acetaldehyde at $0.001,0.002$, and $0.003 \%$ final concentrations. Triplicates of cultures also received these concentrations of EtOH and acetaldehyde separately plus LPS (Escherichia coli no. L-2630 Sigma Chemical Co., St. Louis, MO) at $1,5,10$, and $50 \mu \mathrm{g} / \mathrm{ml}$ final concentrations. As controls, triplicate blood samples and mononuclear cells cultures also received LPS or media alone. These control and treated cultures were incubated at $37^{\circ} \mathrm{C}$ for $2-24 \mathrm{hr}$ in $5 \% \mathrm{CO}_{2}$ and $95 \%$ air incubator. At 2-, 4-, 8-, and 24-hr intervals, treated and control samples were centrifuged at $900 \times g$ for $10 \mathrm{~min}$ at $4^{\circ} \mathrm{C}$, and the plasma and culture supernatants were separated, diluted 1:1 with RPMI 1640 media supplemented with $1 \% \mathrm{FBS}$, and stored at $-20^{\circ} \mathrm{C}$ until assayed for TNF. The viability of leukocytes was examined at different periods of culture by trypan blue dye exclusion assay. The viability of alcohol-treated cultures was not affected and was found to be similar to that of control cultures.

\section{TNF Assay}

The TNF activities of the treated and control blood plasma fluids/ culture supernatants were determined by a cytotoxicity assay using TNFsensitive WEHI 164 subclone 13 cell line (the generous gift of Dr. Daniel G. Remik, Department of Pathology, University of Michigan, Ann Arbor, MI). The method of measuring TNF was described or detailed earlier ${ }^{39}$ and was standardized in our laboratory using human recombinant TNF (rTNF). The WEHI cell line is very sensitive to the cytotoxic effect of TNF and can detect as low as $2 \mathrm{pg} / \mathrm{ml}$ of TNF. Briefly, plasma/ culture supernatants were serially diluted with RPMI $1640+1 \%$ FBS media and were added at $100 \mu \mathrm{l}$ quantities directly into the 96 well plates (Costar, Cambridge, MA). WEHI 164 cells resuspended at a concentration of $5 \times 10^{5}$ cells $/ \mathrm{ml}$ in RPMI 1649 media containing $10 \%$ FBS and $300 \mu \mathrm{g} / \mathrm{ml}$ of fresh glutamine $+0.5 \mu \mathrm{g} / \mathrm{ml}$ of actinomycin D (Calbiochem, Boehring Diagnostic, LaJolla CA) was added to each well in 100 $\mu$ l aliquots. As a standard, human rTNF (Peprotech, Rocky Hill, NJ) at different dilutions was included in the assay. The plates were incubated at $37^{\circ} \mathrm{C}$ for $20 \mathrm{hr}$, after which $20 \mu \mathrm{l}$ of 3-[4,5-dimethylthiazol-2-yl]2,5 diphenyltetrazolium bromide (Sigma, $5 \mathrm{mg} / \mathrm{ml}$ ) was added to each well and further incubated for $4 \mathrm{hr}$ at $37^{\circ} \mathrm{C}$. One hundred and fifty $\mu \mathrm{l}$ of supernatant was removed from each well and $100 \mu$ l of isopropanol:0.04 $\mathrm{N} \mathrm{HCl}$ was added to develop the dark blue crystals. The plates were covered with aluminum foil and allowed to remain at room temperature overnight to dissolve the crystals. Then the plates were read at $550 \mathrm{~nm}$ in an ELISA reader. The amount of TNF in the test supernatants was calculated on the basis of the standard curve that was obtained using the rTNF used as a standard in the same assay.

In TNF neutralization assay, antihuman TNF- $\alpha$ and $-\beta$ antibodies (rabbit polyclonal antisera, Sigma) were used at a concentration of 1:80 dilution to give maximum inhibitory effect as determined by previous experiments. In brief, the test samples containing TNF were incubated for $1 \mathrm{hr}$ at $37^{\circ} \mathrm{C}$ with anti-TNF sera and were then used in TNF assay using WEHI cell line as described.

To investigate the possibility that metabolites of EtOH may alter the production of TNF, we studied one of the primary metabolites of EtOH, acetaldehyde on LPS-induced TNF production by whole blood. The final concentrations of acetaldehyde used were $0.001,0.002$, and $0.003 \%$.
The choices of these concentrations were based on previously published reports of acetaldehyde concentration as determined in vivo. ${ }^{40,41}$

\section{Data Analysis}

Data were analyzed using repeated measures analyses of variance (ANOVA) (samples $\times$ doses) and Pearson correlation. The dose-response relationship of TNF production to alcohol or acetaldehyde was tested using a single linear contrast effect in the ANOVAs. A Pearson correlation was calculated to show the association of the number of monocytes to TNF production in the untreated condition.

\section{RESULTS}

Data presented in Fig. 1 show the kinetics of LPSinduced TNF in the plasma samples harvested at 2, 4, 8, and $24 \mathrm{hr}$ after incubation of whole blood with LPS. Plasma samples from blood incubated with LPS for $2 \mathrm{hr}$ contained $86 \mathrm{ng} / \mathrm{ml}$ of TNF. The maximum level of TNF was produced at $4 \mathrm{hr}$, the values of TNF being $175 \mathrm{ng} /$ $\mathrm{ml}$. The TNF production was found to be lowered at 8 and $24 \mathrm{hr}$, the values being 140 and $103 \mathrm{ng} / \mathrm{ml}$, respectively. Based on this finding, further experiments were performed using 4-hr incubation periods of blood with LPS.

Data presented in Fig. 2 show a dose-response effect of LPS on TNF production by normal blood. LPS at 1,10 , and $50 \mu \mathrm{g} / \mathrm{ml}$ produced 86,189 , and $160 \mathrm{ng} \mathrm{TNF} / \mathrm{ml}$ of plasma, respectively. Because LPS at $10 \mu \mathrm{g} / \mathrm{ml}$ concentration consistently produced maximal level of TNF in our hand $(189 \mathrm{ng} / \mathrm{ml})$, that concentration was used in our subsequent experiments. Data presented in Fig. 3 show a significant correlation between the number of monocytes and TNF production in the blood samples as calculated by the Pearson correlation coefficient. TNF productions was highly correlated with the number of monocytes ( $r=$ $0.86, p<0.0001)$. Data presented in Table 1 show the number of monocytes and the levels of TNF produced by whole blood in response to LPS in the presence and absence of $\mathrm{EtOH}$. EtOH produced a dose-dependent

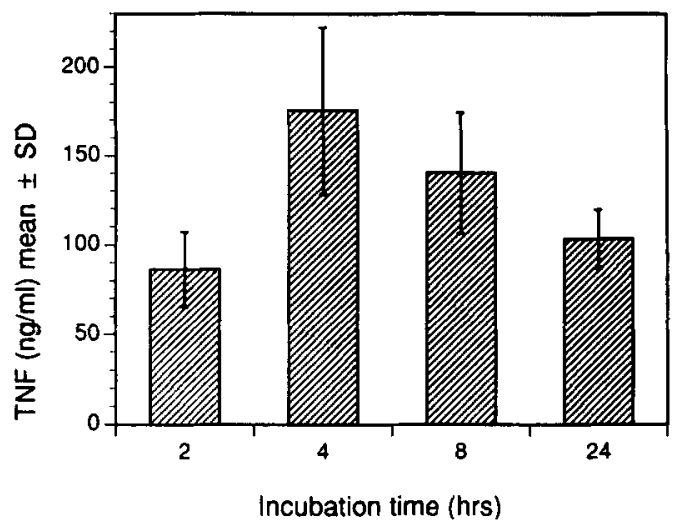

Fig. 1. Kinetics of TNF release in LPS-stimulated human whole blood. Aliquots of whole blood samples ( $1 \mathrm{ml}$ ) were cultured with $10 \mu \mathrm{g} / \mathrm{ml}$ of LPS for $2,4,8$, and $24 \mathrm{hr}$ at $37^{\circ} \mathrm{C}$. Plasma samples were assayed for TNF levels in a bioassay using a TNF-sensitive WEHI 164 subclone 13 cell line. A total of five separate experiments using five different blood samples were studied. Values are expressed as mean \pm so. Mean monocyte count in these blood samples was $641 \pm 108(\mathrm{sD}) / \mathrm{ml}$ of blood. 


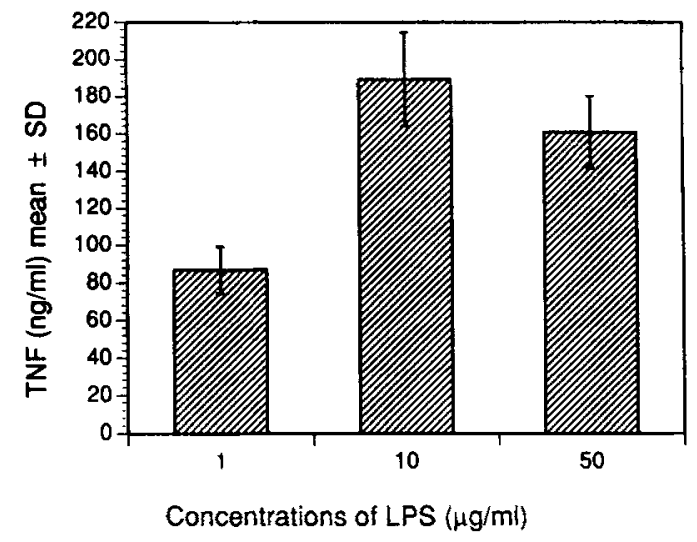

Fig. 2. Dose-response effect of LPS on TNF production by normal whole blood. Aliquots of a $1 \mathrm{ml}$ blood sample were incubated with different concentrations of LPS for $4 \mathrm{hr}$ at $37^{\circ} \mathrm{C}$, and the plasma samples were quantitated for TNF using WEHl cell assay. Data represent mean \pm SD of five separate experiments using five different donors performed in triplicate. TNF levels in the plasma of blood cultured without LPS produced a negligible level of TNF. Mean monocyte count in these blood samples was $749 \pm 102(\mathrm{SD}) / \mathrm{ml}$ of blood.

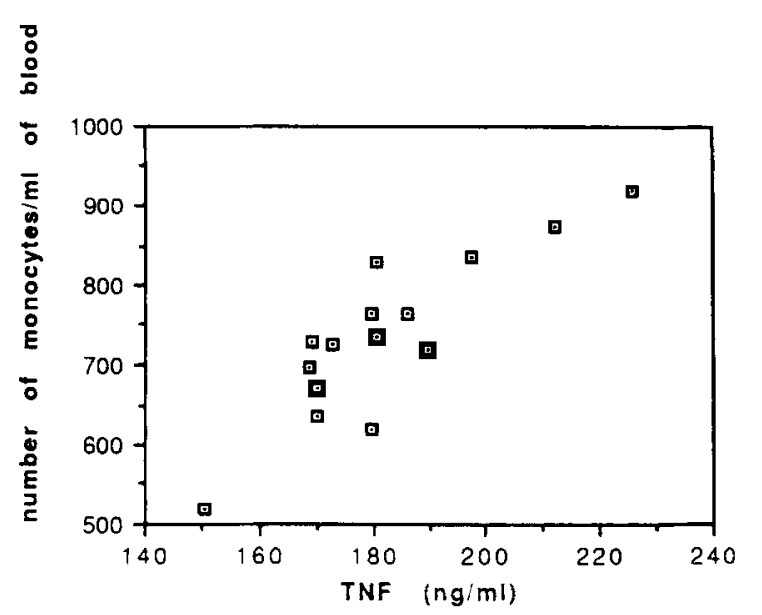

Fig. 3. Correlation between TNF production and number of monocytes. Number of monocytes and LPS-induced TNF production by 15 samples presented in Table 1 have been calculated by the Pearson correlation coefficient evaluation. For descriptions on culture conditions, see table 1 footnotes.

suppression of LPS-induced TNF production. TNF production was affected by alcohol concentration $[F(3,42)=$ $160.72, p<0.0001$ ]; the linear component of this dose effect accounted for most of the variance $[F(1,42)=419.8$, $p<0.0001$ ], indicating a strong dose-response relationship. Data presented in Table 2 show the levels of TNF produced by ficoll-hypaque separated total mononuclear cells in response to LPS in the presence and absence of different concentrations of EtOH. Total mononuclear cells cultured with LPS in the presence of $0.1,0.2$, and $0.3 \%$ EtOH differed in TNF production $[F(3,9)=26.11, p<$ $0.0001]$, and EtOH produced a dose-dependent suppression of TNF production [linear contrast $F(1,9)=75.24, p$ $<0.0001]$. These data demonstrate that alcohol at intoxicating levels in vivo can significantly suppress TNF production.

To examine the isotype of TNF produced in response to LPS, neutralization assay using anti-TNF- $\alpha$ and $-\beta$ antisera was performed. Data presented in Table 3 showed that anti-TNF- $\alpha$ antibodies significantly $(p<0.02)$ neutralized the TNF activity in the test fluid, whereas antiTNF- $\beta$ antibodies only marginally inhibited the TNF activity. A combination of anti-TNF- $\alpha$ and $-\beta$ almost completely $(p<0.001)$ inhibited the TNF activity. This suggests that LPS-induced TNF in our culture may be primarily produced by monocytes.

To examine the specificity of alcohol-induced suppression of TNF production, experiments were performed to assess the effect of acetaldehyde, a primary metabolite of alcohol on TNF production by normal blood. Data presented in Fig. 4 show that acetaldehyde at 0.001, 0.002, and $0.003 \%$ concentrations similar to in vivo concentrations $\mathrm{s}^{40,41}$ did not inhibit LPS induced TNF production by normal blood. There was no significant concentration effect $[F(3,12)=0.47, p>0.10]$, nor was the linear contrast significant $[F(1,12)=0.74, p>0.10]$.

\section{DISCUSSION}

Previous studies have shown that alcohol consumption is associated with abnormalities of humoral ${ }^{17-19}$ and cellular immunity, ${ }^{20-24}$ including dysfunctions of suppressor, ${ }^{24-27}$ helper, ${ }^{28}$ and cytotoxic lymphocyte activities, ${ }^{29-33}$ and production of various soluble immune mediators. ${ }^{34}$ Rats fed with diet containing EtOH also indicated a loss in cells from the thymus and lymph nodes, and showed reduced proliferative response to concanavalin $\mathrm{A},{ }^{42}$ whereas their ability to produce IL-2 and the numbers of IL-2 receptors were not affected. ${ }^{22}$ The effects of alcohol on the production and release of various cytokines by effector cells and on the functions of various effector cells responding to various stimuli have not been clearly elucidated. Previous studies have shown that acute EtOH intoxication in rats markedly suppressed serum and lung TNF elicited in response to LPS, as well as suppressed neutrophil recruitment in the alveoli of rats. ${ }^{37}$ Recent studies have shown that acute alcohol administration markedly reduced $S$. aureus- or $K$. pneumoniae-induced TNF activity in lung lavage fluids of rats. ${ }^{38}$ D'Souza et al. ${ }^{43}$ have shown that acute EtOH administration decreased the circulating serum TNF levels in rats. Administration of rTNF has been shown to enhance the bactericidal capacity of the lung against $S$. aureus, ${ }^{44}$ suggesting that TNF plays an important role against infection. Acute alcohol intoxication of rats also showed an alteration of TNF- $\alpha$ receptors on neutrophils. ${ }^{45}$ In the murine model, dietary alcohol did not significantly affect in vitro TNF production, whereas splenocytes from mice fed either EtOH or control diet produced significantly lower levels of mitogen-induced TNF production when cultured with EtOH ${ }^{46}$ EtOH also downregulated TNF- $\alpha$ production of the in vivo-preactivated monocytes of trauma patients. ${ }^{47}$ The results presented in the present study show that alcohol at intoxicating levels in vivo added directly to the normal human whole blood and separated total mono- 
Table 1. Effect of EtOH on LPS-Induced TNF Production by Normal Blood

\begin{tabular}{|c|c|c|c|c|c|}
\hline \multirow[b]{2}{*}{ Sample no. } & \multirow{2}{*}{$\begin{array}{c}\text { No. of } \\
\text { monocyte/ml } \\
\text { of blood }\end{array}$} & \multicolumn{4}{|c|}{ EtOH concentrations $(\% \mathrm{v} / \mathrm{v})$} \\
\hline & & 0 & 0.1 & 0.2 & 0.3 \\
\hline 1 & 728 & 169.3 & 130.2 & 112.7 & 100.9 \\
\hline 2 & 829 & 180.6 & 116.7 & 106.7 & 89.7 \\
\hline 3 & 520 & 150.7 & 132.6 & 118.8 & 98.0 \\
\hline 4 & 875 & 212.0 & 130.1 & 127.6 & 110.0 \\
\hline 5 & 634 & 170.1 & 135.6 & 122.3 & 116.7 \\
\hline 6 & 764 & 179.7 & 132.0 & 110.6 & 86.3 \\
\hline 7 & 919 & 225.8 & 133.2 & 118.6 & 104.7 \\
\hline 8 & 725 & 172.7 & 111.6 & 108.2 & 92.8 \\
\hline 9 & 672 & 170.3 & 120.7 & 108.6 & 105.6 \\
\hline 10 & 718 & 189.6 & 129.9 & 128.2 & 101.1 \\
\hline 11 & 618 & 179.7 & 132.3 & 119.0 & 107.6 \\
\hline 12 & 736 & 180.5 & 131.3 & 114.0 & 85.6 \\
\hline 13 & 836 & 197.7 & 149.7 & 124.2 & 111.3 \\
\hline 14 & 697 & 168.8 & 132.0 & 130.0 & 120.7 \\
\hline 15 & 763 & 185.9 & 122.8 & 120.3 & 114.6 \\
\hline Mean $\pm s D$ & $735.6 \pm 103.5$ & $182.2 \pm 18.6$ & $\begin{array}{l}129.4 \pm 8.9 \\
(p<0.01)\end{array}$ & $\begin{array}{l}118.0 \pm 7.6 \\
(p<0.001)\end{array}$ & $\begin{array}{l}103.0 \pm 11.0 \\
(p<0.001)\end{array}$ \\
\hline
\end{tabular}

One $\mathrm{ml}$ aliquots of whole blood samples were cultured with $10 \mu \mathrm{g} / \mathrm{ml}$ of LPS with or without different concentrations of EtOH for $4 \mathrm{hr}$ at $37^{\circ} \mathrm{C}$. Plasma samples were assayed for TNF levels using a TNF-sensitive WEHI 164 subcione 13 cell line. A total of 15 different blood samples were studied, and the values of TNF were expressed as mean $\pm \mathrm{SD}$.

\begin{tabular}{|c|c|c|c|c|}
\hline \multirow{2}{*}{$\begin{array}{l}\text { Experiment } \\
\text { no. }\end{array}$} & \multicolumn{4}{|c|}{ EtOH concentrations ( $\% \mathrm{v} / \mathrm{v})$} \\
\hline & \multicolumn{3}{|c|}{${ }_{[\mathrm{TNF}(\mathrm{ng} / \mathrm{ml})]^{0.2}}^{0.1}$} & 0.3 \\
\hline 1 & 194.4 & 177.7 & 173.2 & 140.2 \\
\hline 2 & 231.0 & 176.8 & 163.7 & 156.2 \\
\hline 3 & 222.5 & 193.6 & 164.0 & 156.1 \\
\hline 4 & 216.6 & 199.0 & 152.1 & 158.2 \\
\hline Mean \pm SD & $216.6 \pm 14.7$ & $186.8 \pm 11.2$ & $163.3 \pm 8.6$ & $152.7 \pm 8.4$ \\
\hline
\end{tabular}

Peripheral blood mononuclear cells $\left(1 \times 10^{6}\right.$ cells $\left./ \mathrm{ml}\right)$ were cultured for $4 \mathrm{hr}$ with $10 \mu \mathrm{g} / \mathrm{ml}$ of LPS with or without EtOH. Culture supernatants were examined for TNF using WEHI cell assay. TNF levels in culture supernatants produced without LPS manifested negligible levels of TNF (data not shown).

Table 3. Inhibition of TNF Activity by Anti-TNF Antibodies

\begin{tabular}{lclc}
\hline $\begin{array}{c}\text { Treatment of LPS-induced } \\
\text { TNF supernatant }\end{array}$ & TNF $(\mathrm{ng} / \mathrm{ml})$ & & \% inhibition \\
\hline None & $192.8 \pm 14.9$ & & - \\
Anti-TNF- $\alpha(1: 80$ dilution) & $50.3 \pm 7.6$ & $(\rho<0.02)$ & 73.9 \\
Anti-TNF- $\beta$ (1:80 dilution) & $165.5 \pm 15.6$ & $(\rho<0.3)$ & 14.1 \\
Anti-TNF- $\alpha+-\beta$ & $15.2 \pm 2.9$ & $(\rho<0.001)$ & 92.1 \\
\hline
\end{tabular}

Culture supernatants from LPS-stimulated peripheral blood mononuclear cell cultures were incubated with either anti-TNF- $\alpha$ or $-\beta$ or TNF $-\alpha+-\beta(1: 80$ dilutions previously determined to yield maximum TNF inhibition) for $1 \mathrm{hr}$ at $37^{\circ} \mathrm{C}$ and then assayed for TNF using WEHI cell assay. Data represent the mean \pm SD of TNF levels from three experiments performed in triplicate determinations. Statistical significances of the differences between untreated and treated samples were evaluated by Student's $t$ test.

nuclear cells significantly suppressed the LPS-induced TNF production. Blood cultured with different concentrations of EtOH or acetaldehyde without LPS did not induce the production of TNF (data not shown).

Previous studies have shown that TNF is produced by different subsets of circulating T-cells ${ }^{1,5,6}$ and macrophages. ${ }^{10,11}$ TNF can also influence the functions of different cells, including $T, B$, polymorphonuclear, NK, LAK, and macrophages. ${ }^{4-13}$ Alcohol is known to affect a variety of immunological responses of circulating monocytes and T-cells. Because TNF is an important immu-

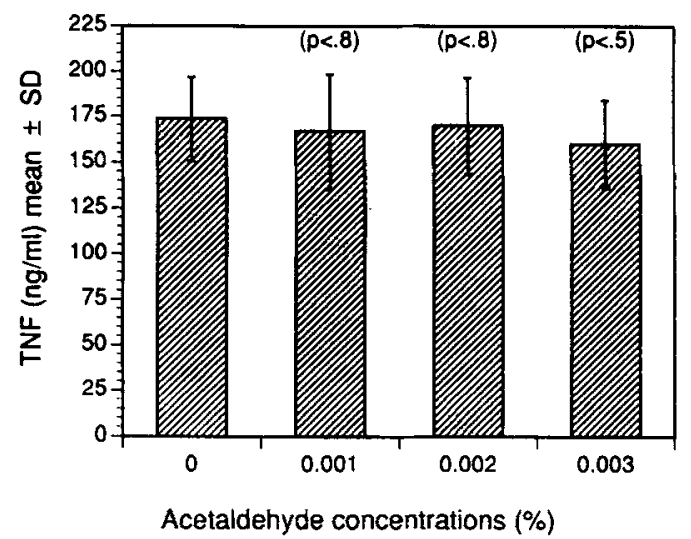

Fig. 4. Effect of acetaldehyde on LPS-induced TNF production by normal blood Aliquots of whole blood samples were cultured with $10 \mu \mathrm{g} / \mathrm{ml}$ of LPS and different concentrations of acetaldehyde for $4 \mathrm{hr}$ at $37^{\circ} \mathrm{C}$. Plasma samples were assayed for TNF levels using a TNF-sensitive WEHI 164 subclone 13 cell line. A total of five separate experiments using five different blood samples were studied, and values were expressed as mean \pm SD. Statistical significance of the differences between the control and acetaidehyde-treated samples were evaluated by two-tailed Student's $t$ test. Mean monocyte count in these blood samples was $673 \pm 93(\mathrm{so}) / \mathrm{ml}$ of biood.

noregulatory molecule and alcohol is known to affect various functions of circulating effector cells, studies on the effect of alcohol on TNF production by circulating monocytes/macrophages or T-cells may be of significance in understanding the pathogenesis of alcohol-associated immune dysfunctions in clinical situations.

Our experiments using whole blood and separated total mononuclear cells produced similar results, although separated mononuclear cells produced slightly higher levels of TNF (216 vs. 182 in tables 2 and 1, respectively). It is possible that the ex vivo model system using whole blood as originally described ${ }^{39}$ may, therefore, be a good model system very similar to in vivo. This system potentially eliminates the artifacts due to adherence phenomenon ${ }^{48}$ 
and also reduces the LPS contamination, because minimal handling of the specimen is required. This system may reduce the confounding variables resulting from isolating cellular subsets for the preparation of TNF. Because cellular interactions are known to influence cytokine productions, ${ }^{48,49}$ the use of whole blood may preserve the cellular integrity. Further, the use of whole blood may also preserve the LPS binding protein facilitating the maximum cellular response to LPS in the assay system. Although the whole blood system may be a limited lymphoid system in comparison with the intact animal and cannot accurately mimic the highly complex in vivo system or intact animals, it is possible that this system has considerable relevance to in vivo situations. Although alcohol levels in tissue and cell membranes may vary, a concentration of $0.3-0.4 \%$ in blood results in severe intoxication, whereas $0.5 \%$ leads to coma. Chronic alcoholics may manifest greater suppressive effects of alcohol on TNF production, because increased levels of alcohol are maintained over longer periods of chronic drinking. It is interesting to note that alcohol as low as $0.1 \%$ could significantly inhibit TNF production by whole blood, whereas alcohol at a similar concentration $(0.1 \%)$ did not manifest any significant effect on TNF production by the separated total mononuclear cells; rather, high concentrations of alcohol $(0.2$ and $0.3 \%)$ were required to mediate a significant inhibition. Our recent studies showed an increase in the number of cells bearing IL-2 R and I 2 markers in alcoholic patients compared with that of matched controls. ${ }^{50}$ The effects of EtOH on the production of TNF by lymphocyte or monocyte subpopulations responding to various specific and nonspecific stimuli in addition to LPS and the number or affinity or avidity of TNF binding receptors present on various subpopulations subjected to isolation procedures in comparison to whole blood needs to be investigated. Our studies using the whole blood samples indicated a significant correlation between TNF production and number of monocytes (Fig. 3). It is important to note that alcohol at $0.1 \%$ and $0.2 \%$ in culture condition levels or similar to those found in humans under varying degrees of intoxication levels significantly suppressed TNF, a potent mediator of inflammatory cascade and an important immunoregulatory substance against various infections. Furthermore, the fact that acetaldehyde, an active metabolite of alcohol, did not produce similar TNF suppression, points to the specificity of this reaction. In summary, our data show that alcohol at intoxicating levels produces suppression of LPS-induced TNF production by whole blood, as well as separated total mononuclear cells. Results of these studies are consistent with that of other in vivo findings $\mathrm{s}^{37,38,43}$ and present direct evidence that one of the mechanisms of alcohol-mediated immunosuppression may be associated with decreased production of TNF. This finding may explain the noted increase in susceptibility to infection reported in alcoholic patients.

\section{ACKNOWLEDGMENTS}

We wish to express our appreciation to Dr. D. G. Remick (University of Michigan) for critical reading of this manuscript, and Gerry Sobkowiak and Carol Sperry for their excellent secretarial assistance.

\section{REFERENCES}

1. Grunfeld C, Palladino MA: Tumor necrosis factor: Immunologic, antitumor, metabolic and cardiovascular activities. Adv Intern Med $35: 45-72,1990$

2. Gelmo BT, Palladini MA, Jaffe HS, et al: Circulating cytokines in patients with metastatic cancer treated with recombinant interleukin-2 and lymphokine-activated killer cells. Cancer Res 48:5864-5867, 1988

3. Beutler B, Cerami A: Cachectin and tumor necrosis factors as two sides of the same biological coin. Nature 320:584-588, 1986

4. Shalaby M, Aggarwal BB, Rinderknecht E, et al: Activation of human polymorphonuclear neutrophil functions by interferon-gamma and tumor necrosis factors. J Immunol 135:2069-2073, 1985

5. Kelso A, Gough NM: Coexpression of granulocyte-macrophage colony stimulating factor, interferon and interleukins 3 and 4 is random in murine alloreactive T-lymphocyte clones. Proc Natl Acad Sci USA $85: 9189-9193,1988$

6. Mosmann TR, Coffman RL: Two types of mouse helper $T$ cell clone: Implications for immune regulation. Immunol Today 8:233-235, 1987

7. Kashiwa $\mathrm{H}$, Wright $\mathrm{S}$, Bonavida $\mathrm{B}$ : Regulation of $\mathrm{B}$ cell maturation; cell differentiation by tumor necrosis factor (TNF). J Immunol 138:1383-1390, 1987

8. Kehrl J, Miller A, Fauci A: Effect of tumor necrosis factor alpha on mitogen activated human B cells. J Exp Med 166:786-791, 1987

9. Jelinek DF, Lipsky PE: Enhancement of human B cell proliferation and differentiation by tumor necrosis factor-alpha and interleukin-1. J Immunol 139:2970-2976, 1987

10. Decker T, Lohmann-Matthes MI, Gifford GE: Cell-associated tumor necrosis factor (TNF) as a killing mechanism of activated cytotoxic macrophages. J Immunol 138:957-962, 1987

11. Oster $W$, Lindemann A, Horn S, et al: Tumor necrosis factor (TNF)-alpha but not TNF-beta induces secretion of colony stimulating factor for macrophages (CSF-1) by human monocytes. Blood 70:17001703, 1987

12. Ortaldo $\mathrm{J}$, Mason $\mathrm{L}$, Mathieson $\mathrm{B}$, et al: Mediation of mouse natural cytotoxic activity by tumor necrosis factor. Nature 321:700-702, 1986

13. Owen-Schaub L, Gutterman J, Grimm E: Synergy of tumor necrosis factor and interleukin 2 in the activation of human cytotoxic lymphocytes; effect of tumor necrosis factor alpha and interleukin-2 in the generation of lymphokine activated killer cell cytotoxicity. Cancer Res 48:788-792, 1988

14. Nawroth P, Bank I, Handley D, et al: Tumor necrosis factor/ cachectin interacts with endothelial cell receptors to induce release of interleukin 1. J Exp Med 163:1363-1375, 1986

15. Bevilacqua MP, Pober JS, Majeau GR, et al: Interleukin 1 (IL-1) induces biosynthesis and cell surface expression of procoagulant activity in human vascular endothelial cells by interleukin 1. J Exp Med 160:618623,1984

16. Pober J, Gimbrone M, Lapierre L, et al: Overlapping patterns of activation of human endothelial cells by interleukin 1, tumor necrosis factor and immune interferon. J Immunol 137:1893-1898, 1986

17. Drew PA, Clifton PM, Labrooy JT, Shearman DJC: Polyclonal B cell activation in alcoholic patients with no evidence of liver dysfunction. Clin Exp Immunol 51:479-486, 1984

18. Delacroix DL, Elkon KB, Genbel AR, Hedgson HF, Dive C, Verman JF: Changes in size, subclass and metabolic properties of serum immunoglobulin A in liver diseases and in other diseases with high serum immunoglobulin A. Am J Clin Invest 71:358-367, 1982

19. Morgan MY, Ross MG, Ng CM, Adams DM, Thomas HC, Sherlock S: HLA-B8, immunoglobulins and antibody responses in alcohol related liver disease. J Clin Pathol 33:488-492, 1980 
20. Chang MP, Norman DC, Makinodan T: Immunotoxicity of alcohol activities of $T$ and $B$ cells of aging mice. Alcohol Clin Exp Res 14:210-215, 1990

21. Jerrels TR, Peritt D, Marietta C, Eckardt MJ: Mechanisms of suppression of cellular immunity induced by ethanol. Alcohol Clin Exp Res 13:490-493, 1989

22. Jerrels TR, Smith W, Eckardt MJ. Murine model of ethanolinduced immunosuppression. Alcohol Clin Exp Res 14:546-550, 1990

23. Ericsson DC, Kohl S, Pickering LK, Davis GS, Faillace LA: Mechanisms of host defense in well nourished patients with chronic alcoholism. Alcoholism 4:261-265, 1980

24. Watson RR, Eskelson C, Hartman BR: Severe alcohol abuse and cellular immune functions. Arizona Med 10:665-668, 1984

25. Hodgson HJF, Wands JR, Isselbaeber KJ: Alteration in suppressor cell activity in chronic active hepatitis. Proc Natl Acad Sci USA 75:1549-1553, 1978

26. Woltjen JA, Zelterman RK: Suppressor cell activity in primary biliary cirrhosis. Diagn Dis Sci 25:104-107, 1980

27. Kawanishi H, Tavassolie H, MacDermott RP, Sheagren JN: Impaired concanavalin-A inducible suppressor $\mathrm{T}$ cell activity in active alcoholic disease. Gastroenterology 80:510-517, 1981

28. McKeever Y, Mahony CO, Whelan CA, Weir DG, Feighery C: Helper and suppressor $\mathrm{T}$ lymphocyte function in severe alcoholic liver disease. Clin Exp Immunol 60:39-48, 1988

29. Abdalla RM, Starkey JR, Meadows GG: Alcohol and related dietary effects on mouse natural killer cell activity. Immunology 50:131137,1983

30. Saxena QB, Nezey E, Adler WH: Regulation of natural killer activity in vivo. II. The effect of alcohol consumption on human peripheral blood natural killer cell activity. Int J Cancer 26:413-417, 1980

31. Stacey NH: Inhibition of antibody dependent cell mediated cytotoxicity by ethanol. Immunopharmacology 8:155-161, 1984

32. Charpentier B, Franco D, Paci L, Charra M, Martin B, Vuitton Friss D: Deficient natural killer cell activity in alcoholic cirrhosis. Clin Exp Immunol 58:107-115, 1984

33. Meadows GG, Blank SE, Duncad DD: Influence of ethanol consumption on natural killer cell activity in mice. Alcohol Clin Exp Res 13:476-479, 1989

34. Roselle GA, Mendenhall CL, Grossman CJ: Ethanol and soluble mediators of host response. Alcohol Clin Exp Res 13:494-498, 1989

35. Nair MPN, Kronfol ZA, Schwartz SA: Effect of alcohol and nicotine on cytotoxic responses of human lymphocytes. Clin Immunol Immunopathol 54:395-409, 1990

36. Nair MPN, Schwartz SA, Kronfol ZA, Saravolatz LA, Heimer EP, Pottathil R, Greden JF: Selective inhibition of natural killer cell activity of lymphocytes from AIDS patients by alcohol. Immunol Infect Dis 2:229-232, 1992

37. Nelson S, Bagby GJ, Summer WR: Alcohol suppresses lipopolysaccharide-induced tumor necrosis factor activity in serum and lung. Life Sci 44:673-676, 1989

38. Nelson S, Bagby GJ, Summer WR: Alcohol-induced suppression of tumor necrosis factor-A potential risk factor for secondary infection in the acquired immunodeficiency syndrome. Prog Clin Biol Res 325:211-220, 1990

39. DeForge LE, Remick DG: Kinetics of TNF, IL-6, and IL-8 gene expression in LPS-stimulated human whole blood. Biochem Biophy Res Commun 174:18-24, 1991

40. Majchrowicz E, Mendelson JH: Blood concentrations of acetaldehyde and ethanol in chronic alcoholics. Science 168:1110-1102, 1970

41. Korsten MA, Matsuzakis F, Fenon L, Leiber CS: High blood acetaldehyde levels after ethanol administration. Difference between alcoholics and nonalcoholics. N Engl J Med 292:386-389, 1975

42. Jerrels TR, Marietta CA, Eckhardt MJ, Majchrowicz E, Weight FF: Effect of ethanol administration on parameters of immunocompetency in rats. J Leukocyte Biol 38:449-510, 1986

43. D'Souza NB, Bagby GJ, Nelson S, Lang CH, Spitzer JJ: Acute alcohol infusion suppresses endotoxin-induced serum tumor necrosis factor. Alcohol Clin Exp Res 13:295-298, 1989

44. Blanchard DF, Djeu JY, Klein TW, Friedman H, Stewart WE II: Effect of acute alcohol intoxication on granulocyte mobilization and kinetics. J Leukocyte Biol 43:429-435, 1988

45. Deaciue IV, D'Souza NB, Bagby GJ, Lang CH, Spitzer JJ: Effect of acute alcohol administration on TNF-alpha binding to neutrophils and isolated liver plasma membranes. Alcohol Clin Exp Res 16:533538,1992

46. Chen GJ, Huang DS, Watzl B, Watson RR: Ethanol modulation of tumor necrosis factor and gamma interferon production by murine splenocytes and macrophages. Life Sci 52:1319-1326, 1993

47. Verma BK, Fogarasi M, Szabo G: Down-regulation of tumor necrosis factor alpha activity by acute ethanol treatment in human peripheral blood monocytes. J Clin Immunol 13:8-22, 1993

48. Standiford TJ, Strieter RM, Chensue SW, Westwick J, Kasahara K, Kunkel SL: IL-4 inhibits the expression of IL-8 from stimulated human monocytes. J Immunol 145:1435, 1990

49. deWall Malefyt R, Abrams J, Bennett B, Figdor CG, deVries JE: Interleukin 10 (IL-10) inhibits cytokine synthesis by human monocytes; an autoregulatory role of IL-10 produced by monocytes. I Exp Med 174:1209, 1991

50. Kronfol Z, Nair MPN, Hill E, Kroll P, Brower K, Greden J: Immune functions in alcoholism: A controlled study. Alcohol Clin Exp Res 17:279-283, 1993 